\title{
ENGINEERING A RECOMBINANT HERPESVIRUS SAIMIRI STRAIN BY CO-CULTURING TRANSFECTED AND PERMISSIVE CELLS
}

Hamad $A^{1}$, Chumakov SP${ }^{2} \otimes$

${ }^{1}$ Moscow Institute of Physics and Technology, Moscow, Russia

${ }^{2}$ Shemyakin-Ovchinnikov Institute of Bioorganic Chemistry of the Russian Academy of Sciences, Moscow, Russia

\begin{abstract}
Recombinant herpesviruses can be used as oncolytic therapeutic agents and high packaging capacity vectors for delivering expression cassettes into the cell. Herpesvirus saimiri is a gamma-herpesvirus that normally infects squirrel monkeys but also has a unique ability to infect and immortalize human lymphocytes while allowing them to retain their mature phenotype and functional activity. Recombination of the Herpesvirus saimiri genome in permissive cells is impeded by its resistance to chemical transfection and electroporation. The aim of this study was to develop an effective method for incorporating expression cassettes into the genome of Herpesvirus saimiri without having to transfect a permissive cell culture. Transfected HEK-293T cells expressing glycoproteins of the measles virus vaccine strain were co-cultured with permissive OMK cells infected with Herpesvirus saimiri. Cell fusion and formation of syncytia stimulated recombination between the viral genome and the expression cassette; this allowed us to obtain a recombinant Herpesvirus saimiri variant without chemical transfection in permissive cells. The genetically modified virus expressed a selectable marker and retained its ability to persist in the cell in the latent state; it also caused immortalization of primary lymphoid cells. The proposed approach allows engineering recombinant Herpesvirus saimiri strains carrying a variety of expression cassettes in its genome.
\end{abstract}

Keywords: herpesvirus, viral vector, recombinant strain, chimeric antigen receptor, CAR

Funding: this study was supported by the Ministry of Science and Higher Education of the Russian Federation (Project ID RFMEFI60418X0205)

Author contribution: Hamad A - manipulations on cell cultures, molecular cloning; Chumakov SP — study plan; manipulations on viral stocks, transfection, titration, data analysis, manuscript preparation

$\triangle$ Correspondence should be addressed: Stepan P. Chumakov Miklouho-Maclay, 16/10, Moscow, 117997; hathkul@gmail.com

Received: 11.11.2019 Accepted: 25.11.2019 Published online: 11.12.2019

DOI: $10.24075 /$ brsmu.2019.079

\section{ПОЛУЧЕНИЕ РЕКОМБИНАНТНОГО ШТАММА HЕRPESVIRUS SAIMIRI ПУTЕМ СОВМЕСТНОЙ КУЛЬТИВАЦИИ ТРАНСФИЦИРОВАННОЙ И ПЕРМИССИВНОЙ КЛЕТОЧНЫХ КУЛЬТУР}

\author{
А. Хамад 1 , С. П. Чумаков \\ Московский физико-технический институт, Москва, Россия \\ 2 Институт биоорганической химии имени М. М. Шемякина и Ю. А. Овчинникова, Москва, Россия
}

\begin{abstract}
Рекомбинантные герпесвирусы можно применять в качестве терапевтических агентов-онколитиков, а также в качестве векторов большой емкости для доставки протяженных экспрессионных конструкций в клетки. Гамма-герпесвирус беличьих обезьян Herpesvirus saimiri обладает уникальной способностью инфицировать человеческие лимфоциты и вызывать их иммортализацию при сохранении зрелого фенотипа и функциональной активности. Проведение рекомбинации генома Herpesvirus saimiri в пермиссивной клеточной культуре затруднено из-за ее устойчивости к химической трансфекции и электропорации. Целью работы являлась разработка эффективного способа введения экспрессионных кассет в геном Негреsvirus saimiri без проведения трансфекции пермиссивной клеточной культуры. Для этого мы использовали совместную культивацию транссицированных клеток НЕК-293Т, экспрессирующих также гликопротеины вакцинного штамма вируса кори, и инфицированных Неrреsvirus saimiri пермиссивных клеток линии ОМК. Слияние клеток и образование синцитиев привели к запуску рекомбинации между вирусным геномом и экспрессионной кассетой, что позволило получить рекомбинантный вариант Herpesvirus saimiri без необходимости проведения химической трансфекции пермиссивных клеток. Трансгенный вариант вируса характеризовался стабильной экспрессией селективного маркера и сохранял способность персистировать в клеточной культуре в латентной форме, а также вызывать иммортализацию первичных лимфоидных клеток. Примененный метод позволяет в короткие сроки получать рекомбинантные варианты Herpesvirus saimiri с введенными в геном разнообразными экспрессионными кассетами.
\end{abstract}

Ключевые слова: герпесвирус, вирусный вектор, рекомбинантный штамм, химерный антигенный рецептор, ХАР

Финансирование: работа выполнена при финансовой поддержке Министерства образования и науки РФ (уникальный код проекта RFMEFI60418Х0205).

Информация о вкладе авторов: А. Хамад - работа с клеточными культурами, молекулярное клонирование; С. П. Чумаков - планирование исследования, работа с вирусными препаратами, трансфекция, титрование, анализ данных и подготовка рукописи.

$\bowtie$ Для корреспонденции: Степан Петрович Чумаков

ул. Миклухо-Маклая, 16/10, г. Москва, 117997; hathkul@gmail.com

Статья получена: 11.11.2019 Статья принята к печати: 25.11.2019 Опубликована онлайн: 11.12.2019

DOI: $10.24075 /$ vrgmu.2019.079

Herpesviridae are a large family of DNA viruses that infect humans and animals. These viruses have a lengthy genome of about 100 to 200 genes that replicate in the nucleus of the infected cell. The assembly of progeny virions and their release from the host cell cause its lysis. Herpesviruses can go into latency. In the latent phase, the full-sized episomal viral DNA is retained in the nucleus and replicates at the same rate as the host cell genome; by attaching to chromatid centromeres, the episomes can be distributed to daughter cells during cell division. Only a small number of specialized genes are expressed in latency, and the infection persists asymptomatically [1]. Members of the gamma-herpesvirus subfamily with tropism for lymphoid cells often have oncogenic potential: the Epstein-Barr virus (EBV) [2] and Kaposi's sarcoma-associated herpesvirus (KSHV) [3] are linked to lymphoproliferative disorders, specifically $\mathrm{B}$-cell neoplasms. EBV is a common cause of spontaneous immortalization of $\mathrm{B}$ cells isolated from the blood of healthy donors [4]. 
The phylogenetic relative of $\mathrm{KSHV}$, a rhadinovirus called Herpesvirus saimiri (HVS), infects New-World squirrel monkeys. This infection is usually asymptomatic and latent. However, it rapidly unfolds in other New-World monkey species, causing acute T-cell leukemias and death. HVS can induce spontaneous immortalization of animal $T$ cells [5]. The same effect was observed when human lymphocytes and natural killer cells were infected with HVS group C strains [6]. In a similar experiment, infected cells acquired the ability for continuous IL2-dependent proliferation without losing their mature T-cell and natural killer cell phenotypes [7]. Three viral genes were reported to retain their expression, including STP, TIP (transforming genes) [8] and ORF73 [9], a homologue of the latency-associated nuclear antigen (LANA) of KSHV required for segregating viral episomes to the host's daughter cells during mitosis [10]. In the daughter cells, the viral genome maintained its latent state; the attempts to induce lytic infection or otherwise track down formation of virions in the immortalized lymphoid cells of humans and New World monkeys ended up in failure. The experiments on macaques demonstrated that autologous reinfusion of $T$ cells immortalized by the most aggressive HVS strain (C488) did not trigger neoplasms. The viral DNA persisted in the samples of peripheral mononuclear cells for at least 16 weeks, and the animals acquired immunity to HVS infection [11].

Homologous recombination of the viral genome inside permissive cells, as well as BAC (bacterial artificial chromosome)-based recombination, can be successfully used to engineer a herpesvirus vector for transgene expression [12]. For example, the genome of the HVS A11-S4 strain has been cloned into the bacterial chromosome. The HVS genome contains a few homologues of bacterial genes the majority of which can be found in other members of the HVS subfamily. The vCD59 gene, however, does not occur in other gamma-herpesviruses; the receptor it codes for is responsible for inhibiting complement-mediated cytotoxicity [13]. This gene is expressed in the lytic phase and is not required for generating viral particles in vitro. In the studies of HVS-based vectors, the $v C D 59$ sequence has been successfully replaced by expression cassettes [14].

The accumulated body of data provides for a hypothesis that HVS can be exploited for the development of novel immunotherapy agents [15]. HVS-transformed T cells and NKs retain their effector function and can be directed against tumor antigens when equipped with chimeric antigen receptors. This approach allows generating an infinite number of effector cells from a relatively small volume of the patient's peripheral blood or through allogeneic cell transplantation. The length of the HVS genome and its good packaging capacity as a vector [14] means that cell immortalization and transduction of the expression cassette can be done in a single step. The aim of this study was to elaborate a fast method for engineering a recombinant HVS C488 strain that can carry a variety of transgenes in its genome.

\section{METHODS}

\section{Cell culture and production of viral particles}

The cell lines used in this study, including HEK-293T (transformed human embryonic kidney cells), OMK (Aotus trivirgatus kidney cells) and A549 (lung carcinoma cells), were provided by American Type Culture Collection (ATCC; USA). The cells were grown in the DMEM-F12 medium (PAA; Austria) supplemented with $10 \%$ fetal bovine serum, $2 \mathrm{mM}$ alanyl glutamine (PanEco; Russia), $20 \mathrm{mM} \mathrm{HEPES,} 100 \mathrm{\mu g} / \mathrm{ml}$ penicillin, and $100 \mathrm{\mu g} / \mathrm{ml}$ streptomycin (PanEco; Russia).
Peripheral blood mononuclear cells (PBMC) were cultured in RPMI-1640 (PAA; Austria) supplemented with 10\% fetal bovine serum, $2 \mathrm{mM}$ alanyl glutamine (PanEco; Russia), $20 \mathrm{mM}$ HEPES, $100 \mu \mathrm{g} / \mathrm{ml}$ penicillin, $100 \mu \mathrm{g} / \mathrm{ml}$ streptomycin, and $70 \mathrm{ng} / \mathrm{ml}$ IL2 (Peprotech; USA). All cells were cultured in a 5\% $\mathrm{CO}_{2}$ atmosphere at $37^{\circ} \mathrm{C}$.

HVS (strain C-488; ATCC VR-1414) was also provided by ATCC. Subconfluent OMK cells were infected with a small amount of the virus $(\mathrm{MOI}<0.1)$ and grown in the culture medium for 5 to 15 days until complete cell lysis was achieved. Then, the virus-containing fluid was harvested and centrifuged at 5,000 $\mathrm{g}$ in the Eppendorf 5920R centrifuge (Eppendorf; Germany) for 15 min to separate cell debris. The supernatant was collected, aliquoted and stored at $-20^{\circ} \mathrm{C}$.

\section{Plasmid constructs}

Plasmids pCG-4AHc $\triangle 24$ and pMD2-F $\triangle 30$ expressing surface glycoproteins of the measles virus had been synthesized previously. The design of the pUC-HVS-OFP vector is described below. Briefly, the vCD59-encoding region of the viral genome was chosen as a recombination site. Homology regions were represented by 600 bp-long sequences corresponding to the $3^{\prime}$ and 5 '-end of vCD59. DNA isolated from the concentrated HVS stock was amplified by PCR. The promoter of the murine spleen focus-forming virus (SFFV), as well as sequences of a puromycin resistance gene (pac) and orange fluorescent protein (OFP), was inserted between the flanking regions of the expression cassette; the T2A signal peptide sequence was inserted between pac and OFP sequences to allow their polycistronic expression. The sequence consisting of two 600 bp-long flanking regions homologous to the vCD59 region of the HVS genome and the expression cassette was cloned into the pUC18 plasmid carrier (Fig. 1) at Notl and BamHI restriction sites. Three components of the cloning fragment were assembled using overlap extension PCR [16]. Primers used for the amplification of HVS regions and the expression cassette are described in Table 1. The sequences of the assembled constructs and recombinant HVS DNA were validated by Sanger sequencing (Eurogen; Russia).

\section{Transfection}

In order to determine the most effective transfection technique for OMK cells, 3 techniques were assessed for efficacy, including transfection by $25 \mathrm{kDa}$ cationic linear polyethyleneimine (PEI-25) (Polysciences; USA), cationic Lipofectamine 2000 (Invitrogen; USA) and electroporation. Twenty-four hours before transfection, the cells were plated onto $10 \mathrm{~cm}$-sized culture dishes (SPL; Korea) in the amount of $2 \times 10^{6}$ cells per dish. The cells were transfected with either circular or linearized pUC-HVS-OFP plasmid (the plasmid was linearized with Notl and $\mathrm{BamH}$ restriction enzymes immediately before transfection). PEI-25-assisted transfection was performed using previously described buffers and conditions [17]. Briefly, plasmid DNA was combined with PEI-25 $(5 \mu \mathrm{g} / \mu \mathrm{l})$ at a $6: 1$ ratio in the lactate buffer $(\mathrm{pH} 4)$ and incubated for $15 \mathrm{~min}$. Then, the OptiMEM reduced serum medium (Invitrogen; USA) was added, and the resulting mixture was introduced into the dishes with growing cell cultures. To determine optimal transfection conditions, transfection was performed with $3,5,10,15$, and $20 \mu \mathrm{g}$ of the circular plasmid and with $1,3,5,10$, and $15 \mu \mathrm{g}$ of the linearized plasmid. Lipofectamine 2000-based transfection was carried out following the manufacturer's protocol. We used 7, 10 and $15 \mu \mathrm{g}$ of circular or linearized plasmid DNA and 17.5, 25 and $37.5 \mu \mathrm{l}$ of the reagent, respectively. Three hours after 


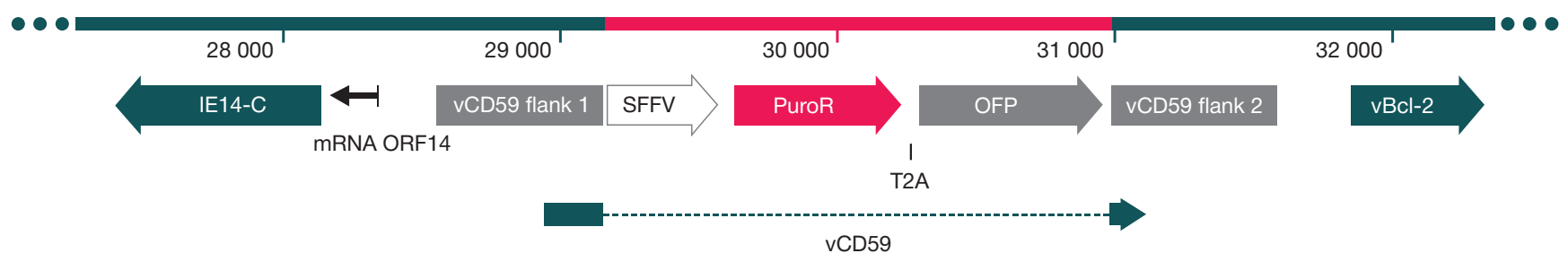

Fig. 1. A schematic representation of the HVS vCD59 region after insertion of the expression cassette. vCD59 flank 1 and vCD59 flank 2 represent recombination homology regions

transfection the medium was replaced with the fresh growth medium used to culture OMK cells. For electroporation, the cells were dissociated from the adherent surfaces using TrypLE (Gibco; USA) and centrifuged in the Eppendorf 5702 centrifuge (Eppendorf; Germany) at 1,100 rpm for $5 \mathrm{~min}$. The cell pellet was resuspended in $500 \mu \mathrm{l}$ of phosphate buffered saline. Electroporation was carried out in electroporation cuvettes with $0.4 \mathrm{~cm}$ interelectrode distance in a GenePulser pulse generator (Bio-Rad; USA) operated at 300 v / 500 uF or 200 v / 250 uF. Prior to electroporation, 5 or $10 \mu \mathrm{g}$ of circular or linearized plasmid DNA were added to the cells. After electroporation, the cells were immediately plated onto $10 \mathrm{~cm}$-sized culture dishes containing $10 \mathrm{ml}$ of full growth medium. Forty-eight hours after transfection, the proportion of the transfected cells was estimated in a FacsVantage SE flow cytometer (BecktonDickinson; USA). Cell viability was assessed using a Cytosmart Cell Counter (Corning; USA) after the cells were dissociated from the adherent surfaces with TrypLE and stained with trypan blue (Paneco; Russia).

Overnight cultures of HEK-293T cells (40 to $60 \%$ confluence) were transfected in the presence of PEI-25 in 6-well plates coated with the OptiMEM culture medium. The cells were transfected with the pUC-HVS-OFP construct containing the expression cassette flanked by homologous regions from the HVS genome and with the plasmids expressing surface glycoproteins $\mathrm{F}$ (fusion protein) and $\mathrm{H}$ (haemagglutinin) of the measles vaccine strain. The F glycoprotein was expressed by

Table 1. Primers used for the assembly of the expression cassette

\begin{tabular}{|c|c|}
\hline Name & Nucleotide sequence \\
\hline vCD59 F1 dir & AGAGAGGCGGCCGCACAGGCTGCTCTTCAGGAGCACCAG \\
\hline vCD59 F1 rev & CAATTGATTTGAGATGCGTTTGAAGC \\
\hline vCD59 F1 bridge & GCAAAATGGCGTTACCTCGAGCAATTGATTTGAGATGCGTTTGAAGC \\
\hline SFFV dir & CTCGAGGTAACGCCATTTTGC \\
\hline OFP rev & СCTGCAGGTCAAGCTTCGAA \\
\hline vCD59 F2 bridge & TTCGAAGCTTGACCTGCAGGTCTGAAACACAGTTAAAGTATCATTGTTG \\
\hline vCD59 F2 dir & TCTGAAACACAGTTAAAGTATCATTGTTG \\
\hline vCD59 F2 BamHI rev & TCTCTCGGATCCGCTGGCAGATATTTCTIITATAAACAGG \\
\hline vCD59 F1 diag dir & GCACAGGCTGCTCTTCAGGAGCACCAG \\
\hline vCD59 F2 diag rev & GCTGGCAGATATTTCTTITTATAAACAGG \\
\hline
\end{tabular}

Table 2. The number and ratios of co-cultured cells and the viral titer in the supernatants

\begin{tabular}{|c|c|c|c|c|}
\hline № & OMK (thous) & HEK-293T (thous) & Ratio \\
\hline 1 & 450 & 1333 & 0.34 & 0.08 \\
\hline 2 & 100 & 1333 & 0.02 & $0.60 \mathrm{E}+03$ \\
\hline 3 & 23 & 1333 & 0 & 0.34 \\
\hline 4 & 68 & 200 & 0.14 & 0.05 \\
\hline 5 & 27 & 200 & $2.56 \mathrm{E}+04$ \\
\hline 6 & 10 & 200 & 3.38 & 0 \\
\hline 7 & 450 & 133 & 2.04 \\
\hline 8 & 225 & 266 & 0.85 & $2.56 \mathrm{E}+04$ \\
\hline
\end{tabular}

the pMD2-F $\triangle 30$ plasmid, whereas $\mathrm{H}$, by the $\mathrm{pCG}-4 \mathrm{AHc} \triangle 24$ plasmid. The pMD2-F $\triangle 30$ plasmid encoded the $\mathrm{F}$ protein with a shortened (minus 30 amino acid residues) C-terminal cytoplasmic domain. The pCG-4AHc $\triangle 24$ plasmid encoded the $\mathrm{H}$ protein sequence in which the first 24 amino acids of the N-terminal cytoplasmic domain were substituted with 4 alanine residues. Protein expression was driven by the cytomegalovirus promoter. During transfection, plasmids pUCHVS-OFP, pMD2-F $\triangle 30$ and pCG-4AHc $\triangle 24$ were combined in the ratio $8: 7: 1$. After HEK-293T cells were incubated with the transfection mix for $3 \mathrm{~h}$, they were dissociated from the dishes using trypsin solution (Paneco; Russia) and co-cultured with OMK cells infected with HVS-C488. The ratios are provided in Table 2.

\section{Virus titration and cloning}

OMK cells were infected with a serial 5 -fold dilution of the viral stock; the procedure was performed in 96-well plates (Greiner; Austria) in 4 replicates. After the cytopathic effect was achieved, the virus was titrated using the Reed-Muench method. Twentyfour hours before the cloning procedure, fresh subconfluent OMK cells were seeded in the 96-well plate. A culture medium containing infected fluorescent OMK cells sorted in a FacsVantage SE flow cytometer (Beckton-Dickinson; USA) was introduced into the wells immediately before HSV-OFP cloning. The concentration of the infected cells per well was 10, 1, 0.1 
and 0.01 . Five to seven days later, the wells were checked for the presence of single fluorescent foci indicating cytotoxicity.

\section{Detecting recombination}

To confirm recombination, the cloned HVS-OFP samples were concentrated using 3kDA Amicon Ultra centrifugal filters (Merck; Germany). The target insertion in the HVS genome was detected by PCR with the vCD59 F1 diag dir and vCD59 F2 diag rev primers. The reaction product of $\sim 3000 \mathrm{bp}$ suggested the presence of the target insertion; the length of $\sim 1200 \mathrm{bp}$ indicated the wild type virus.

\section{Statistical analysis}

Statistical analysis was carried out in Prism 6.0 (GraphPad Software; USA).

\section{RESULTS}

In order to achieve viral genome recombination and engineer a transgenic HVS-C488 variant, we designed an expression cassette containing 2 selectable markers: the orange fluorescent protein (OFP) gene and the puromycin resistance gene coding for puromycin- $\mathrm{N}$-acetyltransferase (Pac). Transfection of permissive OMK cells was the most effective with PEI-25 and the linearized expression cassette (the PEI to DNA ratio was $6: 1 ; 10 \mu \mathrm{g}$ DNA per $2 \times 10^{6}$ cells; Table 3 ). However, the proportion of transfected cells did not exceed $50 \%$ of the total cell population (Fig. 2). Using more DNA and more transfection reagent caused a significant reduction in cell viability. Electroporation did not have a negative effect on cell viability, but the proportion of cells successfully transfected by electroporation was very low. In order to find out if the most effective transfection technique could produce recombinant viral particles capable of inducing expression of selectable markers in the infected cells, we collected clarified viruscontaining culture fluid from OMK cells infected with HVS-C488 and transfected by PEI-25 and the linearized fragment of the expression cassette. Culture fluids were used to infect fresh OMK cells. Subsequent observation of OMK culture did not reveal any presence of cells expressing the fluorescent marker.

An alternative technique for delivering modified DNA into permissive cells was developed to increase the odds of recombination between HSV and the expression cassette. We hypothesized that the ability of OMK cells to maintain the lytic cycle of the virus would be retained after fusion with nonpermissive HEK-293T cells transfected with the expression cassette immediately before fusion. For recombination in the mixed cell system, HEK-293T cells were transfected with the linearized expression cassette or the nonlinearized plasmid containing the cassette and the plasmids coding for the surface glycoproteins of the measles vaccine strain (proteins $\mathrm{F}$ and $\mathrm{H}$ with shortened cytoplasmic domains). The presence of these glycoproteins in the cell membrane induces fusion of contacting cells into syncytia via CD46 binding (Fig. 3E, F). Three hours after transfection, the cells were suspended and seeded into the wells containing OMK cells infected with HVS-C488 $(\mathrm{MOI}=4)$ two days before transfection. Cell ratios and densities are provided in Table 2.

Four days into culture, the supernatant was collected and the virus was titrated. After viral concentrations were compared, sample 5 was chosen for further selection of the monoclonal recombinant virus because it contained the highest viral titer relative to the total number of permissive cells and their ratio to the HEK-293T cells.

Table 3. Conditions for permissive OMK cell line transduction with the expression cassette for HVS recombination and transduction efficacy

\begin{tabular}{|c|c|c|c|}
\hline Transfection technique & Conditions & Percentage of transfected cells & Reduction in viability \\
\hline \multirow{10}{*}{ PEI-25 } & $3 \mu \mathrm{g}$ of circular DNA & $0.7 \% \pm 0.15 \%$ & - \\
\hline & $5 \mu \mathrm{g}$ of circular DNA & $1.82 \% \pm 0.15 \%$ & - \\
\hline & $10 \mu \mathrm{g}$ of circular DNA & $3.73 \% \pm 0.15 \%$ & $+/-$ \\
\hline & $15 \mu \mathrm{g}$ of circular DNA & $3.13 \% \pm 0.15 \%$ & + \\
\hline & $20 \mu \mathrm{g}$ of circular DNA & $1.77 \% \pm 0.15 \%$ & + \\
\hline & $1 \mu \mathrm{g}$ of linear DNA & $<0.15 \% \pm 0.15 \%$ & - \\
\hline & $3 \mu \mathrm{g}$ of linear DNA & $0.85 \% \pm 0.15 \%$ & - \\
\hline & $5 \mu \mathrm{g}$ of linear DNA & $1.91 \% \pm 0.15 \%$ & - \\
\hline & $10 \mu \mathrm{g}$ of linear DNA & $4.76 \% \pm 0.15 \%$ & $+/-$ \\
\hline & $15 \mu \mathrm{g}$ of linear DNA & $3.2 \% \pm 0.15 \%$ & + \\
\hline \multirow{6}{*}{ Lipofectamine 2000} & $7 \mu \mathrm{g}$ of circular DNA & $3.11 \% \pm 0.15 \%$ & - \\
\hline & $10 \mu \mathrm{g}$ of circular DNA & $4.11 \% \pm 0.15 \%$ & - \\
\hline & $15 \mu \mathrm{g}$ of circular DNA & $4.09 \% \pm 0.15 \%$ & + \\
\hline & $7 \mu \mathrm{g}$ of linear DNA & $3.18 \% \pm 0.15 \%$ & - \\
\hline & $10 \mu \mathrm{g}$ of linear DNA & $4.63 \% \pm 0.15 \%$ & - \\
\hline & $15 \mu \mathrm{g}$ of linear DNA & $4.54 \% \pm 0.15 \%$ & + \\
\hline \multirow{8}{*}{ Electroporation } & $5 \mu \mathrm{g}$ of circular DNA, 200V/250uF & $<0.15 \% \pm 0.15 \%$ & - \\
\hline & $10 \mu \mathrm{g}$ of circular DNA, $200 \mathrm{~V} / 250 \mathrm{uF}$ & $<0.15 \% \pm 0.15 \%$ & - \\
\hline & $5 \mu \mathrm{g}$ of linear DNA, 200V/250uF & $<0.15 \% \pm 0.15 \%$ & - \\
\hline & $10 \mu \mathrm{g}$ of linear DNA, 200V/250uF & $<0.15 \% \pm 0.15 \%$ & - \\
\hline & $5 \mu \mathrm{g}$ of circular DNA, 300V/500uF & $<0.15 \% \pm 0.15 \%$ & - \\
\hline & $10 \mu \mathrm{g}$ of circular DNA, 300V/500uF & $<0.15 \% \pm 0.15 \%$ & - \\
\hline & $5 \mu \mathrm{g}$ of linear DNA, 300V/500uF & $<0.15 \% \pm 0.15 \%$ & - \\
\hline & $10 \mu \mathrm{g}$ of linear DNA, 300V/500uF & $<0.15 \% \pm 0.15 \%$ & - \\
\hline
\end{tabular}




\section{ORIGINAL RESEARCH I VIROLOGY}

The medium with the viral particles collected from sample 5 was used to infect OMK cells $(\mathrm{MOI}=0.01)$. Seven days after infection, foci of lytic infection started to form in the confluent culture. Some of the foci contained single plaques constituted primarily by fluorescent cells (Fig. 3B). The population of fluorescent cells was sorted and used to infect permissive cells in a 96-well plate at a concentration of 10, 1, 0.1, and 0.01 infected cells per well. Ten days after infection, 3 (out of 96) single fluorescent plaques appeared in the samples infected at a concentration of 0.1 cells per well; the plaques were most likely formed by individual recombinant viral particles. The virus- containing culture fluid from well 2, where the lytic infection was the most aggressive, was used to produce preparative amounts of the recombinant virus for further analysis.

Sequencing of the vCD59 region of the recombinant HVSOFP revealed the presence of the target expression cassette. Transduction of peripheral blood mononuclear cells and A549 cells with the HVS-OFP virus $(\mathrm{MOI}=5)$ yielded a fraction of fluorescent cells (Fig. 3C, D); in the A549 culture, their proportion was constant for 5 weeks after infection; for PBMC, this proportion was continuously growing (Fig. 3A). This leads us to conclude that our recombinant herpesvirus HVS-OFP

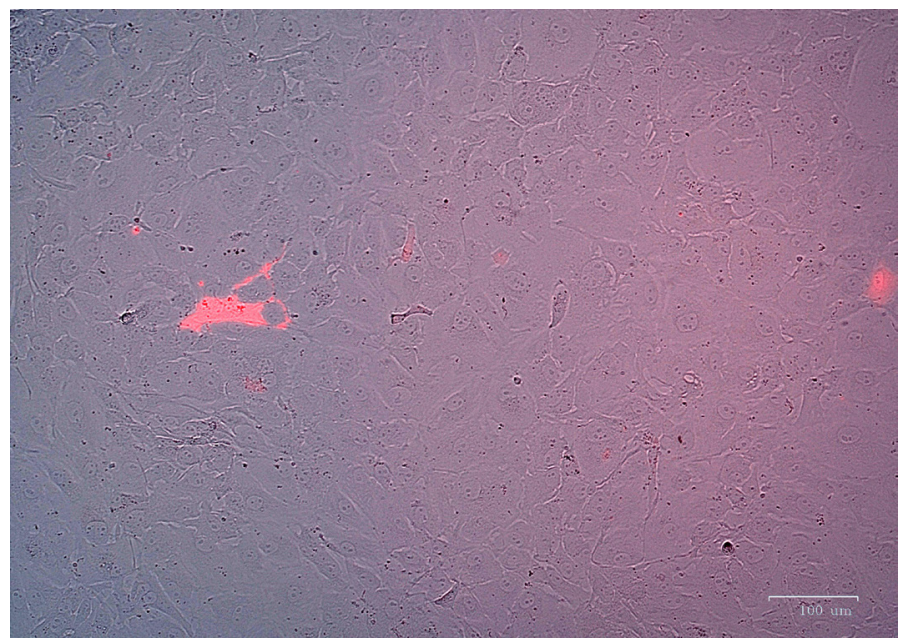

Fig. 2. A population of permissive OMK cells transduced with the expression cassette SFFV-PURO-OFP

A

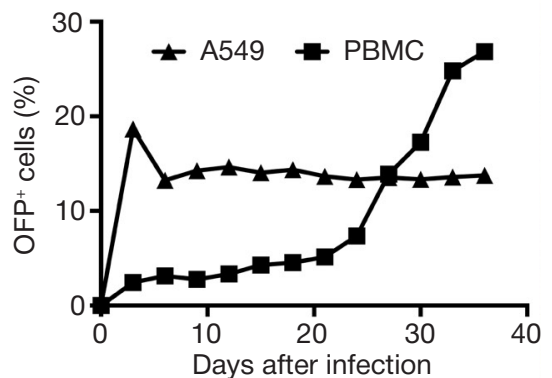

C

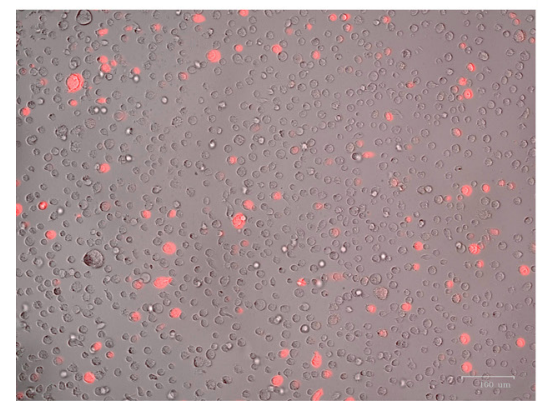

$\mathrm{E}$

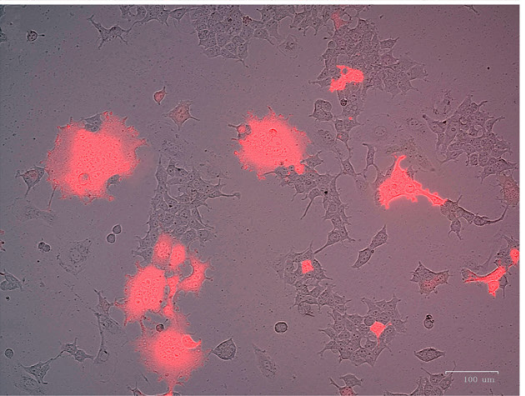

B

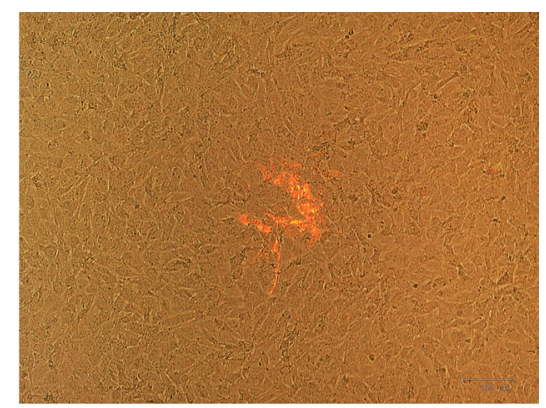

D

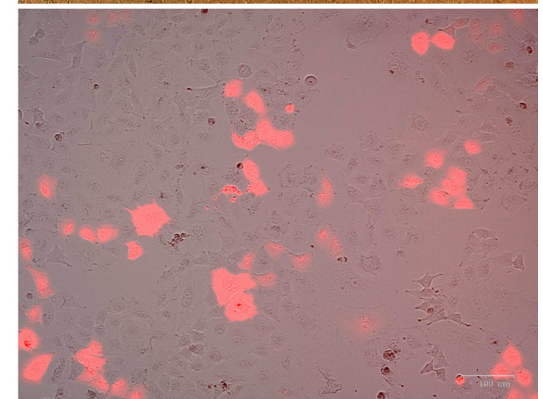

$\mathrm{F}$

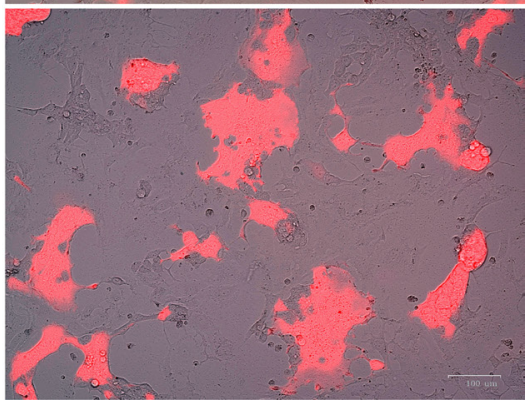

Fig. 3. A. Dynamics of fluorescent populations after HVS-OFP infection. B. A fluorescent plaque formed after OMK cells were infected with the recombinant HVS-OFP. C, D. PBMC (C) and A549 cells (D) transduced with HVS-OFP. E, F. Co-culturing of HEK-293T cells transfected with the recombination cassette and the expressers of the measles virus strain glycoproteins with OMK cells infected with HVS at low $(E)$ and high $(F)$ confluence 
did not lose its ability for latency and immortalization of healthy lymphoid cells. The cassette retained its expression both in the lytic and latent cycles of herpesvirus infection.

\section{DISCUSSION}

We have developed and tested a new approach to the recombination-based genetic engineering of herpesviruses. We tested a few different techniques for increasing the odds of recombination and found that it was necessary to use an expression cassette with two selectable markers. Before the tests, we had hypothesized that puromycin-based artificial selection or sorting of fluorescent OMK cells immediately after transfection would allow us to eliminate nontransfected cells from the population. However, the period between the delivery of the expression cassette and the onset of the cytopathic effect/the release of the virus into the environment was too short for puromycin-based selection, while the stress accompanying fluorescence-based sorting of transduced cells inhibited production of virions. The use of two selectable markers made it more convenient to sort and monitor the proportion of cells successfully transduced with recombinant HVS. Speaking of the HVS-C488 strain, our approach helps to overcome the major obstacle associated with transfection of permissive cells with a transgenic cassette: its low efficacy [18]. Transfection is a key step in all HVS recombination methods described so far $[15,19]$. The efficacy of recombination depends on the length of a recombined fragment, meaning that insertion of larger cassettes expressing several genes will either result in more recombination steps or necessitate the use of larger cell populations for transfection and artificial selection. Our approach is not as effective as BAC-based recombination that has proved its efficacy in the experiments on the HVS genome [20, 21]. Although recombination in eukaryotes is more laborious than BAC-based recombination, it might still be preferred when a single transgene expressor is introduced or when a viral genome is being prepared for cloning into a BAC and a selectable cassette should be inserted for easier recombineering. This application is particularly interesting because the genome of the C488 strain, which is highly effective in transforming human T cells and natural killers [22], has not been cloned into a BAC yet.

Our method has the potential to be applied to the engineering of chimeric viral particles devoid of genes involved in establishing lytic infection and suitable for producing immortalized lymphoid cells for immunotherapy. Notably, the high cloning capacity of the herpesvirus vector [23] allows using it for simultaneous delivery of almost all components of CAR-T cell therapy: mono- and bispecific chimeric antigen receptors or even their full-sized pairs that target a specific cancer cell phenotype; immune checkpoint inhibitors that reduce sensitivity to immunosuppressive signals; inducible expression cassettes for secretion of cytokines that stimulate tumor microenvironment and defense mechanisms that induce suicide of modified lymphocytes and rapidly eliminate them from the patient's organism in case of adverse events or after successful treatment. Given the ability to immortalize peripheral T cells and natural killers, such vector can be used to produce unlimited quantities of agents for allogeneic cellmediated immunotherapy ex vivo.

\section{CONCLUSIONS}

Co-culturing of HEK-293T cells transfected with an expression cassette and the plasmids encoding surface glycoproteins $\mathrm{Fd} 30$ and $\mathrm{Hd} 24$ of the measles virus in the ratio $8: 1: 7$ and permissive OMK cells $(\mathrm{MOI}=4)$ infected with a wild type HVS-C488 in the ratio $27: 20048$ hours before the experiment produced recombinant viral particles $(\sim 3 \%)$ and allowed us to obtain a viral preparation with the integrated expression cassette in only 3 passages. The obtained recombinant herpesvirus HVS-OFP retained its ability to cause lytic infection in permissive OMK cells only and went into latency in A549 cells. The virus immortalized human peripheral blood mononuclear cells, where it persisted in the latent state. The expression cassette was functional during both lytic and latent cycles of the herpesvirus.

\section{References}

1. Davison AJ. Overview of classification. In: Anvin A, Campadelli-Fiume G, Mocarski E, Moore PS, Roizman B, Whitley R, et al., editors. Human Herpesviruses: Biology, Therapy and Immunoprophylaxis. Cambridge, 2007.

2. Javier RT, Butel JS. The history of tumor virology. Cancer Res. 2008; 68 (19): 7693-706. DOI: 10.1158/0008-5472.CAN-083301. PubMed PMID: 18829521.

3. Chang Y, Cesarman E, Pessin MS, Lee F, Culpepper J, Knowles DM, et al. Identification of herpesvirus-like DNA sequences in AIDSassociated Kaposi's sarcoma. Science. 1994; 266 (5192): 1865-9. DOI: 10.1126/science.7997879. PubMed PMID: 7997879.

4. Fu Z, Cannon MJ. Functional analysis of the CD4(+) T-cell response to Epstein-Barr virus: T-cell-mediated activation of resting B cells and induction of viral BZLF1 expression. J Virol. 2000; 74 (14): 6675-9. DOI: 10.1128/jvi.74.14.6675-6679.2000. PubMed PMID: 10864684.

5. Fickenscher H, Fleckenstein B. Herpesvirus saimiri. Philos Trans R Soc Lond B Biol Sci. 2001; 356 (1408): 545-67. DOI: 10.1098/ rstb.2000.0780. PubMed PMID: 11313011.

6. Biesinger B, Muller-Fleckenstein I, Simmer B, Lang G, Wittmann S, Platzer $E$, et al. Stable growth transformation of human $T$ lymphocytes by herpesvirus saimiri. Proc Natl Acad Sci USA. 1992; 89 (7): 3116-9. DOI: 10.1073/pnas.89.7.3116. PubMed PMID: 1313581
7. Vogel B, Tennert K, Full F, Ensser A. Efficient generation of human natural killer cell lines by viral transformation. Leukemia. 2014; 28 (1): 192-5. DOI: 10.1038/leu.2013.188. PubMed PMID: 23787393.

8. Duboise SM, Guo J, Czajak S, Desrosiers RC, Jung JU. STP and Tip are essential for herpesvirus saimiri oncogenicity. J Virol. 1998; 72 (2): 1308-13. PubMed PMID: 9445031.

9. Griffiths R, Whitehouse A. Herpesvirus saimiri episomal persistence is maintained via interaction between open reading frame 73 and the cellular chromosome-associated protein MeCP2. J Virol. 2007; 81 (8): 4021-32. DOI: 10.1128/JVI.02171-06. PubMed PMID: 17267510.

10. Verma SC, Robertson ES. ORF73 of herpesvirus Saimiri strain C488 tethers the viral genome to metaphase chromosomes and binds to cis-acting DNA sequences in the terminal repeats. J Virol. 2003; 77 (23): 12494-506. DOI: 10.1128/jvi.77.23.1249412506.2003. PubMed PMID: 14610173.

11. Knappe A, Feldmann G, Dittmer U, Meinl E, Nisslein T, Wittmann S, et al. Herpesvirus saimiri-transformed macaque $T$ cells are tolerated and do not cause lymphoma after autologous reinfusion. Blood. 2000; 95 (10): 3256-61. PubMed PMID: 10807797.

12. Menotti L, Avitabile E, Gatta V, Malatesta P, Petrovic B, Campadelli-Fiume G. HSV as A Platform for the Generation of Retargeted, Armed, and Reporter-Expressing Oncolytic Viruses. Viruses. 2018; 10 (7). DOI: 10.3390/v10070352. PubMed 
PMID: 29966356.

13. Albrecht JC, Nicholas J, Biller D, Cameron KR, Biesinger B, Newman C, et al. Primary structure of the herpesvirus saimir genome. J Virol. 1992; 66 (8): 5047-58. PubMed PMID: 1321287.

14. White RE, Calderwood MA, Whitehouse A. Generation and precise modification of a herpesvirus saimiri bacterial artificial chromosome demonstrates that the terminal repeats are required for both virus production and episomal persistence. J Gen Virol. 2003; 84 (Pt 12): 3393-403. DOI: 10.1099/vir.0.19387-0. PubMed PMID: 14645920.

15. Hiller C, Wittmann S, Slavin S, Fickenscher H. Functional longterm thymidine kinase suicide gene expression in human $\mathrm{T}$ cells using a herpesvirus saimiri vector. Gene Ther. 2000; 7 (8): 66474. DOI: 10.1038/sj.gt.3301158. PubMed PMID: 10800089.

16. Horton RM, Hunt HD, Ho SN, Pullen JK, Pease LR. Engineering hybrid genes without the use of restriction enzymes: gene splicing by overlap extension. Gene. 1989; 77 (1): 61-8. DOI: 10.1016/0378-1119(89)90359-4. PubMed PMID: 2744488.

17. Fukumoto Y, Obata Y, Ishibashi K, Tamura N, Kikuchi I, Aoyama K, et al. Cost-effective gene transfection by DNA compaction at $\mathrm{pH} 4.0$ using acidified, long shelf-life polyethylenimine. Cytotechnology. 2010; 62 (1): 73-82. DOI: 10.1007/s10616-0109259-z. PubMed PMID: 20309632.

18. Turrell SJ, Whitehouse A. Mutation of herpesvirus Saimiri ORF51 glycoprotein specifically targets infectivity to hepatocellular

\section{Литература}

1. Davison AJ. Ovenview of classification. In: Anvin A, Campadelli-Fiume G, Mocarski E, Moore PS, Roizman B, Whitley R, et al., editors. Human Herpesviruses: Biology, Therapy and Immunoprophylaxis. Cambridge, 2007.

2. Javier RT, Butel JS. The history of tumor virology. Cancer Res. 2008; 68 (19): 7693-706. DOI: 10.1158/0008-5472.CAN-083301. PubMed PMID: 18829521

3. Chang Y, Cesarman E, Pessin MS, Lee F, Culpepper J, Knowles DM, et al. Identification of herpesvirus-like DNA sequences in AIDSassociated Kaposi's sarcoma. Science. 1994; 266 (5192): 1865-9. DOI: 10.1126/science.7997879. PubMed PMID: 7997879.

4. Fu Z, Cannon MJ. Functional analysis of the CD4(+) T-cell response to Epstein-Barr virus: T-cell-mediated activation of resting $B$ cells and induction of viral BZLF1 expression. J Virol. 2000; 74 (14): 6675-9. DOI: 10.1128/jvi.74.14.6675-6679.2000. PubMed PMID: 10864684.

5. Fickenscher $\mathrm{H}$, Fleckenstein B. Herpesvirus saimiri. Philos Trans R Soc Lond B Biol Sci. 2001; 356 (1408): 545-67. DOI: 10.1098/ rstb.2000.0780. PubMed PMID: 11313011

6. Biesinger B, Muller-Fleckenstein I, Simmer B, Lang G, Wittmann S, Platzer $E$, et al. Stable growth transformation of human $T$ lymphocytes by herpesvirus saimiri. Proc Natl Acad Sci USA. 1992; 89 (7): 3116-9. DOI: 10.1073/pnas.89.7.3116. PubMed PMID: 1313581

7. Vogel B, Tennert K. Full F, Ensser A. Efficient generation of human natural killer cell lines by viral transformation. Leukemia. 2014; 28 (1): 192-5. DOl: 10.1038/leu.2013.188. PubMed PMID: 23787393.

8. Duboise SM, Guo J, Czajak S, Desrosiers RC, Jung JU. STP and Tip are essential for herpesvirus saimiri oncogenicity. J Virol. 1998; 72 (2): 1308-13. PubMed PMID: 9445031.

9. Griffiths R, Whitehouse A. Herpesvirus saimiri episomal persistence is maintained via interaction between open reading frame 73 and the cellular chromosome-associated protein MeCP2. J Virol. 2007; 81 (8): 4021-32. DOI: 10.1128/JVI.02171-06. PubMed PMID: 17267510

10. Verma SC, Robertson ES. ORF73 of herpesvirus Saimiri strain C488 tethers the viral genome to metaphase chromosomes and binds to cis-acting DNA sequences in the terminal repeats. J Virol. 2003; 77 (23): 12494-506. DOI: 10.1128/jvi.77.23.1249412506.2003. PubMed PMID: 14610173.

11. Knappe A, Feldmann G, Dittmer U, Meinl E, Nisslein T, Wittmann S, et al. Herpesvirus saimiri-transformed macaque $T$ cells are tolerated and do not cause lymphoma after autologous reinfusion. carcinoma cell lines. J Biomed Biotechnol. 2011; 2011: 785158 . DOI: 10.1155/2011/785158. PubMed PMID: 21197456.

19. Duboise SM, Guo J, Desrosiers RC, Jung JU. Use of virion DNA as a cloning vector for the construction of mutant and recombinant herpesviruses. Proc Natl Acad Sci USA. 1996; 93 (21): 11389-94. DOI: 10.1073/pnas.93.21.11389. PubMed PMID: 8876145.

20. White RE, Calderwood MA, Whitehouse A. Generation and precise modification of a herpesvirus saimiri bacterial artificial chromosome demonstrates that the terminal repeats are required for both virus production and episomal persistence. J Gen Virol. 2003; 84 (Pt 12): 3393-403. DOI: 10.1099/vir.0.19387-0. PubMed PMID: 14645920

21. Collins CM, Medveczky MM, Lund T, Medveczky PG. The terminal repeats and latency-associated nuclear antigen of herpesvirus saimiri are essential for episomal persistence of the viral genome. J Gen Virol. 2002; 83 (Pt 9): 2269-78. DOI: 10.1099/0022-131783-9-2269. PubMed PMID: 12185282.

22. Ensser A, Thurau M, Wittmann S, Fickenscher $\mathrm{H}$. The genome of herpesvirus saimiri $\mathrm{C} 488$ which is capable of transforming human T cells. Virology. 2003; 314 (2): 471-87. DOI: 10.1016/s00426822(03)00449-5. PubMed PMID: 14554077.

23. Macnab S, White R, Hiscox J, Whitehouse A. Production of an infectious Herpesvirus saimiri-based episomally maintained amplicon system. J Biotechnol. 2008; 134 (3-4): 287-96. DOI: 10.1016/j.jbiotec.2008.01.012. PubMed PMID: 18328588.

Blood 2000: 95 (10): 3256-61. PubMed PMID: 10807797.

12. Menotti L, Avitabile E, Gatta V, Malatesta P, Petrovic B, Campadelli-Fiume G. HSV as A Platform for the Generation of Retargeted, Armed, and Reporter-Expressing Oncolytic Viruses. Viruses. 2018; 10 (7). DOI: 10.3390/v10070352. PubMed PMID: 29966356.

13. Albrecht JC, Nicholas J, Biller D, Cameron KR, Biesinger B, Newman $C$, et al. Primary structure of the herpesvirus saimiri genome. J Virol. 1992; 66 (8): 5047-58. PubMed PMID: 1321287.

14. White RE, Calderwood MA, Whitehouse A. Generation and precise modification of a herpesvirus saimiri bacterial artificial chromosome demonstrates that the terminal repeats are required for both virus production and episomal persistence. J Gen Virol. 2003; 84 (Pt 12): 3393-403. DOI: 10.1099/vir.0.19387-0. PubMed PMID: 14645920.

15. Hiller C, Wittmann S, Slavin S, Fickenscher H. Functional longterm thymidine kinase suicide gene expression in human T cells using a herpesvirus saimiri vector. Gene Ther. 2000; 7 (8): 66474. DOI: 10.1038/sj.gt.3301158. PubMed PMID: 10800089

16. Horton RM, Hunt HD, Ho SN, Pullen JK, Pease LR. Engineering hybrid genes without the use of restriction enzymes: gene splicing by overlap extension. Gene. 1989; 77 (1): 61-8. DOI: 10.1016/0378-1119(89)90359-4. PubMed PMID: 2744488.

17. Fukumoto Y, Obata Y, Ishibashi K, Tamura N, Kikuchi I, Aoyama K, et al. Cost-effective gene transfection by DNA compaction at $\mathrm{pH} 4.0$ using acidified, long shelf-life polyethylenimine. Cytotechnology. 2010; 62 (1): 73-82. DOI: 10.1007/s10616-0109259-z. PubMed PMID: 20309632

18. Turrell SJ, Whitehouse A. Mutation of herpesvirus Saimiri ORF51 glycoprotein specifically targets infectivity to hepatocellular carcinoma cell lines. J Biomed Biotechnol. 2011; 2011: 785158. DOI: 10.1155/2011/785158. PubMed PMID: 21197456

19. Duboise SM, Guo J, Desrosiers RC, Jung JU. Use of virion DNA as a cloning vector for the construction of mutant and recombinant herpesviruses. Proc Natl Acad Sci USA. 1996; 93 (21): 11389-94. DOI: 10.1073/pnas.93.21.11389. PubMed PMID: 8876145.

20. White RE, Calderwood MA, Whitehouse A. Generation and precise modification of a herpesvirus saimiri bacterial artificial chromosome demonstrates that the terminal repeats are required for both virus production and episomal persistence. J Gen Virol. 2003; 84 (Pt 12): 3393-403. DOI: 10.1099/vir.0.19387-0. PubMed PMID: 14645920

21. Collins CM, Medveczky MM, Lund T, Medveczky PG. The terminal 
repeats and latency-associated nuclear antigen of herpesvirus saimiri are essential for episomal persistence of the viral genome. J Gen Virol. 2002; 83 (Pt 9): 2269-78. DOI: 10.1099/0022-131783-9-2269. PubMed PMID: 12185282.

22. Ensser A, Thurau M, Wittmann S, Fickenscher $\mathrm{H}$. The genome of herpesvirus saimiri C488 which is capable of transforming human
T cells. Virology. 2003; 314 (2): 471-87. DOI: 10.1016/s00426822(03)00449-5. PubMed PMID: 14554077.

23. Macnab S, White R, Hiscox J, Whitehouse A. Production of an infectious Herpesvirus saimiri-based episomally maintained amplicon system. J Biotechnol. 2008; 134 (3-4): 287-96. DOI: 10.1016/j.jbiotec.2008.01.012. PubMed PMID: 18328588. 